\title{
Pregnancy in a post-cardiac transplant patient
}

Mia Dubravčić ${ }^{\star}$,
Maja Čikeš,
Drvoje Jurin,
Daniel Lovrić,
Jure Samardžić,
Jana Ljubas Maček,
Olvo Planinc,
Marijan Pašalić,
Dina Jakuš,
Dora Fabijanović,
Davor Miličić,
DBoško Skorić

University of Zagreb School of Medicine, University Hospital Centre Zagreb, Zagreb, Croatia
RECEIVED:

December 6, 2020

ACCEPTED:

December 18, 2020

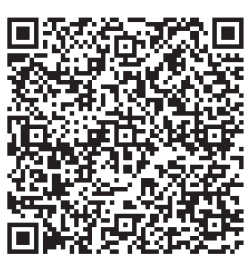

\author{
KEYWORDS: heart transplant, pregnancy, immunosuppression. \\ CITATION: Cardiol Croat. 2021;16(1-2):20. | https://doi.org/10.15836/ccar2021.20
}

*ADDRESS FOR CORRESPONDENCE: Mia Dubravčić, Klinički bolnički centar Zagreb, Kišpatićeva 12, HR-10000 Zagreb, Croatia. / Phone: +385-98-9549898 / E-mail: dubravcic.mia@gmail.com

ORCID: Mia Dubravčić, https://orcid.org/0000-0003-0441-4772 • Maja Čikeš, https://orcid.org/0000-0002-4772-5549 Hrvoje Jurin, https://orcid.org/0000-0002-2599-553X • Daniel Lovrić, https://orcid.org/0000-0002-5052-6559 Jure Samardžić, https://orcid.org/0000-0002-9346-6402 • Jana Ljubas Maček, https://orcid.org/0000-0001-7171-2206 Ivo Planinc, https://orcid.org/0000-0003-0561-6704 • Marijan Pašalić, https://orcid.org/0000-0002-3197-2190 Nina Jakuš, https://orcid.org/0000-0001-7304-1127 • Dora Fabijanović, https://orcid.org/0000-0003-2633-3439 Davor Miličić, https://orcid.org/0000-0001-9101-1570 • Boško Skorić, https://orcid.org/0000-0001-5979-2346

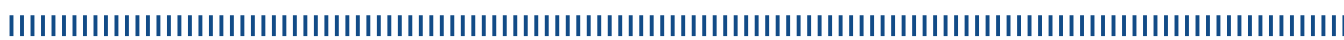

Background: The number of transplant patients of childbearing age has increased. Decisions regarding the pregnancy management are challenging. Close monitoring includes screening for complications including rejection, graft dysfunction, and infection. First pregnancy in a post-cardiac transplant patient was reported in 1988 in a female patient who conceived less than 2 years post-transplant. Since then, there are many case reports that have demonstrated successful pregnancies in solid organ transplant recipients. ${ }^{1-3}$

Case report: We present a case of 42-years-old female patient who underwent heart transplant 2016. In 2018 the patient expressed wishes for pregnancy and childbirth. A multidisciplinary team of cardiologists and gynecologists was formed and preconception and genetic counseling given. Before pregnancy we adjusted standard immunosuppressant therapy - mycophenolate mofetil was excluded, prednisone was continued in dose of $5 \mathrm{mg}$ daily, and tacrolimus titrated to achieve concentration of 10-15 ng/ml. One month later, myocardial biopsy excluded graft rejection and 6 months later patient conceived naturally. Graft function was assessed by regular monthly NT-proBNP check. Echocardiography performed at $4^{\text {th }}$ and $35^{\text {th }}$ week of pregnancy showed normal graft function. In 36 th week of pregnancy patient was admitted to our Department due to renal failure and hyperkalemia and was treated conservatively. Due to labor contractions on the 7th day of hospitalization, urgent caesarean section was performed in general anesthesia. Our patient gave birth to a healthy male newborn, without postpartal complications. Standard immunosuppressant therapy with mycophenolate mofetil, tacrolimus and prednisone was introduced immediately after birth. Repeated myocardial biopsy performed in the follow-up showed no signs of graft rejection.

Conclusion: Pregnancy and childbirth in post-cardiac transplant patient is feasible and should be managed by multidisciplinary team of healthcare providers.

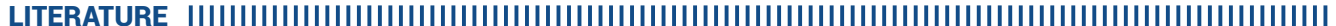

1. Abdalla M, Mancini DM. Management of pregnancy in the post-cardiac transplant patient. Semin Perinatol. 2014 Aug;38(5):318-25. https://doi.org/10.1053/j.semperi.2014.04.022

2. Cowan SW, Davison JM, Doria C, Moritz MJ, Armenti VT. Pregnancy after cardiac transplantation. Cardiol Clin. 2012 Aug;30(3):441-52. https://doi.org/10.1016/j.ccl.2012.05.001

3. Löwenstein BR, Vain NW, Perrone SV, Wright DR, Boullón FJ, Favaloro RG. Successful pregnancy and vaginal delivery after heart transplantation. Am J Obstet Gynecol. 1988 Mar;158(3 Pt 1):589-90. https://doi.org/10.1016/0002-9378(88)90035-X $\square$ Cardiologia Croatica 2021;16(1-2):20. 